\title{
Inter-Regional Cooperation (KAD) based institution in the tourism sector in Madura
}

\author{
Eni Sri Rahayuningsih
}

Faculty of Economics and Business, Universitas Trunojoyo Madura, Indonesia

Correspondence author email: eni.rahayuningsih@trunojoyo.ac.id

\begin{tabular}{|l|l|l|l|l|}
\hline DOI: & Received: & Revised: & Accepted: & Published: \\
$10.22437 /$ ppd.v9i1.10758 & 23.10 .2020 & 26.01 .2021 & 27.01 .2021 & 30.04 .2021 \\
\hline
\end{tabular}

\begin{abstract}
This study aims to analyze the Inter-Regional Cooperation (KAD) institution in the tourism sector in Madura to support Presidential Regulation Number 80 of 2019 concerning the DEWI CEMARA program (Tourism Village with Smart, Independent, and Prosperous Communities). This qualitative research has used the triangulation method for data collection. This study shows great potentials have supported tourism development in Madura; yet, they have complex problems. This problem has led to the establishment of the KAD in the tourism sector in Madura, whose aim is to exploit the regional potential and overcome tourism problems collectively using mutual benefit principles. From 2017 to the present, these objectives have not been achieved due to the following reasons: (1) KAD has not been supported by the commitment of regional heads who are willing to facilitate cross-sector and cross-regional cooperation and resources; (2) KAD has not been supported by cross-sectoral and cross-regional planning documents; (3) no good cooperation occurs among the government, the private sector and the community; and (4) moral hazard such as egoistic/opportunistic, free riders, and tragedy of common are still obviously seen.
\end{abstract}

Keywords: Government, Inter-regional, Moral hazard, Tourism, Tragedy of commons JEL Classification: $\mathrm{H} 1, \mathrm{H} 11, \mathrm{Z} 3$

\section{INTRODUCTION}

To accelerate Economic Development in Madura, the government issued Presidential Regulation Number 80 of 2019, which contains 37 programs. One of the government policy programs is the DEWI CEMARA program (Tourism Village with Smart, Independent, and Prosperous Communities). To run this program requires support from all strong institutions ranging from villages to regions and across regions.

This new institutional economy needs to be supported by several institutional instruments such as rules of the game and players to overcome market failures caused by imperfect information, externalities, free riders, and tragedies of common to manage - all resources and provision of public goods (Lincoln, 2010). Institutions aim to regulate interaction patterns and direct actors' behavior so that order and the absence of opportunistic attitudes in distributing economic resources fairly and equitably can be guaranteed (Badulescu \& Badulescu, 2017).

Inter-Regional Cooperation Based Institution or translated into Indonesian as 
Kerjasama Antar Daerah (KAD) in Madura's field is a collaborative program involving four districts on Madura Island. KAD has objectives such as promoting agreement on common rules of the game and regulating cooperative relations for tourism actors regarding resource potential and provision of public goods across sectors and regions by always referring to the principle of mutual benefit. The slow development pace of tourism has previously driven the establishment of KAD in the tourism sector on Madura Island in Madura. This situation is caused by weak governance of tourism institutions such as sectoral egos and regional egos; Meanwhile, cooperation between stakeholders across sectors and regions is less harmonious.

To strengthen Madura Island's tourism development institution, four districts on Madura Island have agreed to establish KAD since 2017. The agreement was signed by four heads of regencies in Madura and approved by the Governor of East Java Province. Up to now, KAD, however, has not shown an optimal role in advancing tourism development in Madura.

Based on this background, this study aims to analyze the institutional KAD in the tourism sector in Madura by focusing on two aspects, namely: the rule of the games and players. Following these objectives, this paper's contribution is to evaluate the KAD institution's performance achievements in the tourism sector in Madura. The evaluation results are used as recommendations for improving the institutional performance of $\mathrm{KAD}$ in the tourism sector in Madura. It is recommended that formal and informal rules for playing should be in synergy to improve the institutional performance of KAD. Likewise, it is recommended that actors cooperate by their respective roles. The institutional performance of the KAD in the tourism sector in Madura becomes more effective and efficient.

This study uses the theoretical basis of the New Institutional Economics (NIE). NIE is relevant to be used as a theoretical basis for analyzing the institutional complexity of KAD in the Tourism Sector in Madura.

The institutional economic theory consists of three groups, namely: Neo-Classical Economics (NCE), Old Institutional Economics (OIE), and New Institutional Economics (NIE). NCE theory is a mainstream economic thought that emphasizes market mechanisms. NCE is built using the assumption of perfect competition that is not realistic in the real world, including perfect information, zero transaction costs, and free players in and out of the market ( North, 1994; Furubotn \& Richter, 2010).

OIE theory is a branch of economics that does not have a basic classical or neoclassical economics theory. The OIE theory opposes neoclassical thinking because, in its approach, it is considered that it does not include humanistic aspects. OIE theory is not a physical institution but rather economic behavior that is driven by considerations and feelings that generally apply in certain circumstances and times (Haris et al., 1995; North, 1990).

The NIE theory comes by modifying, developing, and opening the black box of the NCE and OIE theories' weaknesses in solving economic problems in the real world. NIE depicts imperfect information, transaction costs, and barriers to entry and exit from the market. Imperfect information has consequences for transaction costs. The imperfect information (asymmetric information), the higher the transaction costs incurred by economic actors. In the NIE's view, efforts are needed to minimize transaction costs.

In this study, the authors use four levels of evolution of the NIE theory to analyze the institutional KAD in tourism in Madura. Based on NIE, this study focuses on two aspects: The rule of the games and the players.

The four levels of evolution of the NIE theory (Williamson, 2000), namely: NIE 
level, emphasize the relationship between formal and informal rules. Informal rules that have been embedded in society, such as tradition, religion, norms, customs, and mindset (embeddedness), are partly synergistic with formal rules and support KAD performance. Still, some other informal rules are not synergistic with formal rules and hamper KAD's performance. Informal rules that support the performance of KAD, namely: Islamic teachings on the virtue of carrying out activities in the congregation or collective action and the Madurese culture of voluntary cooperation. Meanwhile, informal regulations that hinder the performance of KAD include primordial culture, client patrons, and embeddedness as a mindset of inefficient bureaucratic behavior.

NIE level II emphasizes property rights' economics, which consists of rules of the game (law), politics, and government bureaucratic functions. In this case, regional autonomy has placed the regional head as the holder of property rights or the regional government bureaucracy's highest authority. Thus, the performance of the bureaucratic stakeholders of the four districts in Madura, members of KAD, is strongly influenced by the commitment of the regional head. The weak commitment of regional heads has implications for the low performance of KAD because it is related to resource access.

Level III emphasizes governance structures, sustainable contracts, and transaction cost economics. The presence of incompetent officials, changes in officials, and relatively short terms of office in the local government bureaucracy have resulted in rational opportunistic behavior, unsustainable contracts, and high transaction costs.

Level IV emphasizes resource efficiency and incentive structures. So far, the KAD game rules have not demonstrated authority, governance, and principal-agent relationships. It results in inefficient use of resources and low incentives for KAD members to perform well.

This NIE needs to be supported by several institutional instruments such as rules of the game and players to overcome market failures caused by imperfect information, externalities, moral hazard, free riders, and tragedies of common to manage all resources and provide public goods (Lincoln, 2010).

\section{METHODS}

This study uses a qualitative approach to reveal the meaning of the institutional phenomenon of KAD in the tourism sector in Madura. This research focuses on the meaning of non-sensual empirical facts and phenomena (noumena), so it is not nomothetic; the KAD institution in the tourism sector in Madura involves two institutional aspects: the rules of the game (rule of the games) and the actors (players).

This present study's data collection has been carried out using several techniques such as FGD, in-depth interviews, observation, and document review. This triangulation method becomes possible because the writer has direct access to any KAD activities and has built a good rapport with the key informants.

The FGD was attended by invited KAD member informants and discussed various matters according to the data and information needed. In-depth interviews in this study were carried out by interviewing KAD member informants at their respective assignments or places agreed upon to obtain the required data and information. Observation in this study was carried out by attending and observing various KAD events, including coordination meetings, festivals, exhibitions, calendar arrangements, and Madura tour packages. Document review is carried out by reviewing various document reports and research results related to Madura Tourism Development.

This present study's primary data sources are the informants or people who are purposively selected and considered to have a lot of information about the phenomenon 
being studied. Meanwhile, the secondary data of this study are obtained from numerous documents.

This study has gone through several stages in data analysis: (1) collecting primary and secondary data (collection) from various sources and methods (triangulation); (2) reducing data (reduction) by summarizing, selecting, determining themes and patterns. As a result, the reduced data provide a clear and easy picture for the researcher to present the data; (3) presenting data (display). After data reduction, data are presented in narration, tables, graphs, matrix, or network forms, and (4) presenting a conclusion. Conclusions in qualitative research are in the form of a clear description or description of an object.

\section{RESULTS AND DISCUSSION}

\section{Potentials and problems}

Madura Island is a part of East Java Province which consists of four districts: Bangkalan, Sampang, Pamekasan, and Sumenep. The development of tourism in Madura is supported by marine tourism and Islamic Madurese culture's potential.

The potential of marine tourism in Madura Island is spread across many islands, with the largest number of islands (126 islands) in the Sumenep Regency. Madurese culture's potential has a strong Islamic color because the majority of the Madurese population is Muslim. The Islamic culture of Madura is indicated by a large number of mosques and prayer rooms, Islamic boarding schools, Islamic schools (Madrasah), and the graves of ulama.

Although Madura has great tourism potential, tourism development in Madura has been facing several problems, including:

1. Tourism destinations are not yet supported by accessibility, infrastructure, human resources, and a good investment climate;

2. Tourism marketing has not been supported by a good market, partnership, image, and promotion; and

3. The tourism industry has not been supported by a good database, certification, product competitiveness, business partnerships, business credibility, and environmental responsibility.

4. Tourism institutions have not been supported by commitment and good cooperation from cross-sector and cross-regional stakeholders

5. These problems cause tourism potential in Madura to below, and the result cannot facilitate other related sectors, community welfare, and regional income.

\section{Rule of the games of KAD}

Institutional economics is a branch of economics that studies the influence and role of formal and informal rules of play on economic performance at both the macro and micro levels (Bardhan, 1989; Commons, 2001; Hayami \& Kikuchi, 1999; North, 1994; Yeager, 1999). Informal institutions are unwritten institutions in society, such as customs, traditions, agreements, conventions, and various names and designations. Meanwhile, formal institutions are written regulations such as laws, agreements, contractual agreements, economic, business, political, and other regulations, including agreements that apply at international, national, regional, and local levels, including formal institutions.

Informally, the collective action of KAD on Madura tourism is facilitated by social capital originating from Islamic religious norms and ethnic Madurese culture: (1) Islamic teachings that prioritize worship in groups (congregation) rather than 
individually; (2) high self-esteem; (3) hard work ethic; (4) the culture of wandering or traveling; (5) strong kinship ties; (6) strong emotional ties between ethnic Madurese; and (7) a strong culture of group cooperation (Rahayuningsih, 2014).

Formally, the KAD in the Madura tourism sector is supported by some regulations:

1. Law No. 32 of 2004 concerning Regional Government. This law has mandated the importance of KAD to improve community welfare by referring to the principles of efficiency and effectiveness of public services, synergy, and mutual benefit;

2. Government Regulation No. 50 of 2007 concerning Procedures for Implementation of Regional Cooperation regulates KAD, such as the principles of cooperation, the subject of cooperation, objects and forms of cooperation, and procedures for cooperation. It includes provisions regarding BKAD and financing;

3. Presidential Regulation No. 5/2010 concerning RPJMN 2010-2014 (especially Book III) provides general direction on regional development in general and, in particular, the potential of KAD to build synergies between regions;

4. Presidential Regulation Number 80 of 2019 states that the acceleration of economic development in Madura is carried out through the development of transportation infrastructure and the development of DEWI CEMARA;

5. Regulation of the Minister of Home Affairs Number 22 of 2009 concerning Technical Guidelines for Regional Cooperation contains the scope of KAD technical instructions, namely: KAD technical guidelines and technical guidelines for regional cooperation with third parties;

6. Regulation of the Minister of Home Affairs Number 23 of 2009 concerning Procedures for the Guidance and Supervision of Regional Cooperation contains procedures for the guidance and supervision of KAD by the Minister of Home Affairs and the Governor in stages: exploration, negotiation, signing, implementation, and termination; and

7. Joint agreement of four regents in Madura approved by the Governor of East Java (Bangkalan Regent, Sampang Regent, Pamekasan Regent and Sumenep Regent on November 2, 2017 at Pamekasan Number 134.4 / 001 / 433.011 / 2017; Number 415.4 / 26 / XI / SEKBER / 434.011 / 2017; Number 847.4 / 432.401 / SEKBER / 11/2017; Number 415.4 / XI.06-SEKBER / 435.022.1 / 2017 concerning the Establishment of a Joint Secretariat for Inter-Regional Cooperation in the Madura Region.

To strengthen the institution and the KAD program's sustainability, actors with good morals need to support the game's formal and informal rules. In his book entitled The Theory of Moral Sentiments and Wealth of Nations, Adam Smith states that a country's harmony and economic welfare will be created if the country's economic institutions are based on good morals and a balance of bargaining power. If every economic actor is rational and profit-oriented, then economic institutions' problem is related to the presence or absence of good morality and balanced bargaining power. This principle has implications for transactions that can benefit one party but also harm another party.

The ideal rationality of economic actors is based on good morals (sympathetic/altruistic) so that the business process runs by applicable norms and benefit all parties. In reality, people encounter complex problems related to unbalanced needs and abilities. They have limited abilities, but it is not always the case with their unlimited needs. People are likely to become egoistic/opportunistic to fulfill these indefinite needs. For example, they manage to benefit themselves personally by all 
means, which may harm others (Yustika, 2008).

In Madurese tourism KAD institution, moral hazard (egotistical/opportunistic, free rider, and tragedy of commons), imbalance in resources and commitment causes sectoral egos and regional egos that hinder KAD's performance are still identified, particularly in relation to the commitments of actors in implementing the rules of the game agreed.

\section{The purpose of KAD}

KAD in the tourism sector in Madura is expected to become a regulator and facilitator of cooperation from stakeholders across sectors and regions so that tourism development in Madura goes well.

The rational choice theory in economics states that humans are rational, meaning that all human actions aim to maximize their self-interest (self-interest / egoistic/opportunistic) benefits. Even the government apparatus, when making policies, does not detach themselves from being motivated to benefit their interests.

While socially humans cannot live alone, they need cooperation with other humans by carrying out complementarity and mutual benefit. This concept is a rational reason that drives people to take collective action to overcome various problems such as alleviating poverty, managing shared resources and public goods, increasing bargaining power, and paying attention to cost efficiency (Ritzer \& Goodman, 2001).

Regarding tourism development in Madura, each district has different weaknesses and strengths. They finally have to work together to solve the problem by making better use of the tourism potential. Strong institutions for sustainability are needed to carry out group collaboration or collective action. Institutions are networking whose establishment comes from various patterns of interaction. Arsyad (2010) states that the interaction pattern can be seen from two aspects: the game and the actors' rules. The perpetrator is the party who constructs and implements the rules according to their status and role. KAD actors in the tourism sector in Madura consist of tourism stakeholders from four districts in Madura (Bangkalan, Sampang, Pamekasan, and Sumenep). The KAD actors have rules of the game in duties, functions, behavior patterns, values, and norms mutually agreed.

Each institution has one specific function: educational institutions, economics, religion, tourism, and others. Institutions have structures and roles recognized and accepted by society, including values, rules, norms, beliefs, morals, ideas, doctrines, desires, needs, orientation, etc. Organizational aspects contain structure, roles, relationships between roles, integration between sections, general structure, comparison of textual structures with real structures, authority structures, relations of activities with goals, aspects of solidarity, membership, profiles, patterns of power, etc. (Sudaryanto, 1999).

Each institution has specific goals such as (1) directing individual behavior to achieve mutually planned goals; (2) increasing certainty and order in society according to the rules of the game; (3) reducing opportunistic behavior through the formation of structures or patterns of interaction between individuals; and (4) limiting human behavior that tends to cheat in distributing economic resources fairly and equitably (Libecap, 1989; Ostrom, 1990; North, 1994; Kasper \& Streit, 1999; Suradisastra, 2008).

Under Law No. 32 of 2004, the general objective of KAD is to improve community welfare based on the efficiency and effectiveness of public services, synergy, and mutual benefits. In particular, the objectives of the KAD in the tourism sector in Madura are as follows: 
1. to optimize the strategic role of the tourism sector to encourage the development of various other related sectors;

2. optimizing the utilization of regional potential based on considerations of efficiency, synergy, and mutual benefit across sectors and regions;

3. gather greater strength to face problems and work with a higher level of productivity and efficiency;

4. achieve higher progress. Each area transfers knowledge, experience, skills, and information to each other. Thus, each region will try to advance or develop itself from the results of joint learning;

5. increase bargaining power. Each region will be able to have a better bargaining position and strive for their interests to external parties and higher government structures;

6. prevent conflict. Regions that were previously competing or already involved in the conflict can be more tolerant and try to benefit from or learn from the conflict;

7. create justice. Each region will feel that it benefits from transparency in cooperative relations. Each region involved in the collaboration has equal access to the information created or used;

8. maintain cooperation sustainability. Each region is committed to maintaining mutually beneficial relationships in a sustainable manner;

9. eliminating sectoral egos. Tourism development is multi-sector in nature;

10. eliminate the ego area. The regional ego tendencies can be minimized, and a vision of togetherness can grow together.

KAD has the duty and function to assist Regional Heads in carrying out several things such as management, monitoring, and evaluating the implementation of tourism development, providing input and suggestions. KAD also has the authority to coordinate member regions to plan joint activity programs. There needs to be a commitment to balanced cooperation between KAD and all regional heads in Madura. The commitment of the regional head strongly influences the performance of KAD in achieving its goals.

Starting from 2017 to 2020 , KAD has made various efforts to strengthen institutions such as (1) implementing an agreement on a joint secretariat with KAD every two years, starting from Sampang and then moving to Sumenep; (2) hold regular meetings with KAD stakeholders to coordinate and agree on various matters; (3) forming a WhatsApp group under the name Madura Raya as a communication medium; (4) agree on the Visit Madura program with professional management which is funded jointly; (5) compile an annual event calendar for four districts in Madura which are collaborated in the Madura visit package; (6) compiling tour packages covering four districts in Madura; (7) participated as a participant in the 2019 Majapahit International Fair exhibition event on behalf of Madura Raya and won first place; (8) compiling a plan to organize the 2020 Madura Raya festival; (9) make plans to celebrate the anniversary of each district with the concept of togetherness. Each district invites four regional heads and a complete range of regional leaders; (10) synergistically compile the tourism planning documents across regions based on local potential and wisdom; and (11) implementing the DEWI CEMARA program.

Some of the problems that hinder institutional strengthening in KAD are as follows: (1) the function of the joint secretariat with KAD is ineffective due to moral hazard and imbalance in commitment between KAD and regional heads; (2) regular meetings with KAD stakeholders to coordinate and agree on various matters are not effective because several districts are not present, those who attend are representatives who do not have the authority to make decisions. As a result, the results of the meeting 
were only minutes without being realized; (3) the WhatsApp group with the name Madura Raya as a joint communication medium has not been functioning effectively because there has not been active participation from the regional head; (4) the annual calendar of events for the 4 districts in Madura which were collaborated in the Madura visit package has not been realized; (5) tour packages covering 4 districts in Madura have not been realized; (6) the plan to hold Madura Raya festival 2020 until the end of 2020 has not been realized; (7) Only Sumenep Regency, Bangkalan Regency, the tourism planning documents have been completed since 2018 but until now they have not been ratified, Sampang and Pamekasan Districts are still in the process of being drafted; (8) weak commitment of regional heads and regional leaders as indicated by budget allocations, human resources, facilities and infrastructure that are not in accordance with needs, as well as various important events that are not attended by 4 regional heads and a complete range of regional leaders; (9) there is no strong commitment from stakeholders across sectors to support tourism development; (10) combining several fields in one service causes less focus on tourism development. For example, The Department of Tourism, Culture, Youth and Sports; and (11) placement of tourism agency leaders and staff are not by their competencies and needs.

The weakness of this institution creates feelings of disappointment and reduces the spirit of togetherness. In the long term, it is feared that this problem will reduce mutual trust and disrupt the sustainability of KAD.

\section{KAD models}

KAD in the tourism sector in Madura uses the principles of transparency, accountability, effectiveness, consensus, mutual benefit, and advances for all parties. Under its principles, the Madura Tourism KAD model combines three complementary models: The handshake Agreement Model, the Joint Agreement, and the Jointly-formed authorities.

The KAD Model of Handshake Agreement refers to political commitment and trust among cooperating regions. This form of cooperation is quite efficient and more flexible due to the support of strong social capital such as mutual trust, strong emotional ties as fellow Madurese, and shared interests in developing tourism as a source of regional income and community welfare.

The KAD Joint Agreement model refers to the participation of all members in carrying out the cooperation process. Each member has the same control and responsibility for all activities and cooperation.

KAD uses a jointly-formed authorities model that takes the form of a Joint Secretariat. Local governments of KAD members agree to delegate control, manage and assume responsibility to a body consisting of representatives from the relevant local governments. This agency has the authority to execute policies, programs, and activities it administers.

Several regencies have agreed to take on the secretariat's role with KAD in turns every two years. In the first period (2017-2019), the joint secretariat of KAD Madura was Sampang Regency. The next period (2020-2021) is Sumenep Regency. In addition to the joint secretariat, each district also has a sub-secretariat that also involves district government staff from each Madura KAD member.

The joint secretariat has the mandate as the party responsible for coordinating the implementation of mutually agreed programs.

\section{KAD resources}

According to Government Regulation no. 50 of 2007, BKAD personnel come 
from government employees from SKPD in the region, and they are members of the secretariat. BKAD is led by a Coordinator, namely Assistant 1 for Regional Government Government. In the running KAD, the coordinator is assisted by the Secretary, Deputy Secretary, General Affairs, and Program and Reporting Affairs, which are occupied by Assistant 1 staff for Government Affairs. To carry out public services cooperation, KAD coordinates with SKPD to prepare plans, compile programs in the environment, tourism, and transportation.

The availability of human, financial, facilities, and infrastructure is an important input for implementing KAD policies. The financing source for implementing the BKAD plan is each region's responsibility, whose members come from government and non-government institutions.

Whereas regional heads have low commitment, the need for human, financial, facilities and KAD infrastructure cannot be fulfilled. Also, this situation is exacerbated by the lack of enthusiasm for cooperation from cross-sector and cross-regional stakeholders.

\section{KAD actors}

The social interdependence and resource limitations of the four districts in Madura have formed an incentive structure for KAD members to carry out Mutually Beneficial Collective Action, pool resources to optimize the management of tourism potential and solve limited resources (Miller, 1977).

$\mathrm{KAD}$ in the Madura tourism sector is a collective action involving several actors, namely: government, private, civil society, and academics. The government is the Central Government, the Provincial Government of East Java, and the four district governments in Madura. The central government acts as a regulator and provider of funds for tourism development. The Provincial Government of East Java has a role in coordinating tourism affairs involving the four districts in Madura. The local governments of the four districts in Madura play a role in implementing the agreements made by Inter-Regional Cooperation Agency (BKAD).

The private company is involved in tourism development in Madura, and they play a role as a contributor to CSR funds, investors, tourism industry actors, and government cooperation partners. Communities are religious leaders, cultural figures, traditional leaders, and groups involved in tourism development activities in Madura. Academics come from higher education institutions and play a role in compiling planning documents, research, and community empowerment through outreach, education, training, and mentoring activities.

Collective action is facilitated by social capital and has been proven to have reduced transaction costs in supervision and enforcement of regulations due to interdependence between group members. An individual's decision-making considers the costs and benefits of resource use for him and needs other individuals' expectations. It is related to the social character of the Madurese community; a strong orientation to interdependence, expectations of individual behavior, and norms of reciprocity. The agreed social or customary sanctions make incentives to violate rules or become free riders can be suppressed ( Rohima, 2013).

KAD Madura Tourism's collective action's success and sustainability are influenced by social capital's cognitive and structural aspects. Social capital's cognitive aspect is social capital, which includes mental processes (internalization of awareness) of norms, values, attitudes, or behavior (beliefs), etc. The internalization process affects the morale of the collective action actors. Their actions are influenced by dynamic 
factors, including the quality of trust, solidarity, cohesiveness, cooperation, generosity, and others. The final output of the internalization process is ideas or expectations that lead to collective behavior that guarantees collective benefits. Cognitive social capital exists in the form of civic culture and has a strong influence on behavior. Social capital in this category usually called predispose, encourages people to take beneficial collective action (Mutually Beneficial Collective Action). Another characteristic of social capital in this category is intrinsic or not physically visible.

The structural aspects of social capital are the building blocks of how social capital is structured. Therefore, in contrast to cognitive social capital, social capital has extrinsic or physical characteristics according to structural aspects. But both have in common that the final output is also in the form of ideas or expectations that lead to beneficial collective action - structural social capital in the form of networks, groups, or other interpersonal relationships. The dynamic factor is the horizontal and vertical relationship. Structurally, social capital takes the form of social organization, which facilitates beneficial collective action. Therefore, social capital in this category is commonly referred to as assets.

Social capital's cognitive and structural aspects converge on ideas or expectations that lead to mutually beneficial collective action behavior. Cognitive social capital affects why communities are willing to take beneficial collective action, while structural social capital functions to facilitate beneficial collective action. Social capital in cognitive and structural aspects will be more effective if supported by complementary interactions between formal and informal institutions (Krishna \& Uphoff, 1999).

Formal and informal norms facilitate the cognitive aspects of the Madura Tourism KAD. Formal norms include regulations related to KAD. Informal norms include Islamic religious norms and Madurese cultural norms derived from Islamic teachings (congregation). Meanwhile, the structural aspects of the Madura Tourism KAD were facilitated by BKAD.

Internalization of formal and informal norms is a social capital from a cognitive aspect that affects the actors' rationality to take collective action in the KAD of Madura Tourism.

The establishment of the KAD in the tourism sector in Madura is an implementation of the formal norms of law no. 32 of 2004, Government Regulation no. 50 of 2007, Regulation of the Minister of Home Affairs Number 22 of 2009, and Regulation of the Minister of Home Affairs Number 23 of 2009.

The establishment of the KAD in tourism in Madura is an implementation of informal norms derived from the teachings of Islam and Madurese culture. One of the motivations for the collective action of KAD is to carry out Islamic teachings that prioritize collective action (congregation) rather than individuals. This teaching motivates the Muslim community in Madura to take collective action (in congregation) in life, including tourism management. Like the congregational prayer services held at the mosque, the Madura Tourism KAD's collective action is carried out on the awareness, volunteerism, and good intentions of the perpetrator for the good of himself or his group. Ghutong Rojhung culture or Gotong Royong, ethnic ties and strong kinship are social assets that support the collective action of KAD.

The collective action of KAD in the tourism sector in Madura is rational because each actor has the goal of benefiting from the cooperation carried out through pooling the resources owned by all KAD members (Goldfield \& Gilbert, 2018).

The rationality of KAD Madurese tourism actors supported by good morals (altruistic/sympathetic) will form social capital, which has positive implications in the 
form of productive, effective, efficient behavior and positively impacts all parties in the short and long term. On the other hand, rationality supported by moral hazard (egoistic/opportunistic) forms social capital, which has negative implications such as the tragedy of the commons and has a negative impact on all parties in the short and long term (Hausman \& Mcpherson, 1993).

Heterogeneous collective action groups have greater potential for moral hazard because there is a tendency that everyone wants to cooperate with others who have something in common. The existence of moral hazard behavior (egotistical/ opportunistic, free rider, and tragedy of common) triggers another moral hazard. Group size also influences collective action's success: the larger the group size, the more efficient, the greater the potential for moral hazard. KAD in the tourism sector in Madura is a homogeneous collective action group with a relatively small size, so that the potential for moral hazard is also relatively small. Without a strong commitment from all regional heads and their staff, the institution and performance of KAD will become weak.

Among all sectors, the tourism sector is the most strategic sector to facilitate other sectors' development. However, developing the tourism sector requires support from other sectors. Among the four districts that are members of KAD Madura, each has different potentials and resources. The low awareness of mutual needs between sectors and regions causes sectoral and regional egos to emerge.

\section{CONCLUSIONS AND RECOMMENDATIONS}

\section{Conclusions}

Madura tourism development is hampered by the weakness of the KAD institution in the Madura tourism sector: (1) the KAD program has not been supported by the commitment of all regional heads to facilitate cross-sector and cross-regional cooperation and meet resource needs; (2) KAD has not been supported by a synergy of planning documents across sectors and regions; (3) there are no good cooperation between the government, private sector and society; and (4) indications of moral hazard, such as: egoistic/opportunistic, free riders, and tragedy of commons.

\section{Recommendations}

Strengthening the Madura tourism sector's KAD institution requires a written commitment agreement from all regional heads in Madura. This agreement functions to facilitate cross-sectoral and cross-regional stakeholder cooperation, fulfill resources according to needs, and minimize potential moral hazards, such as: egoistic/opportunistic, free riders, and tragedy of commons.

\section{REFERENCES}

Badulescu, D., \& Badulescu, A. (2017). Rural Tourism Development through Crossborder Cooperation. The Case of Romanian-Hungarian Cross-border Area. Eastern European Countryside, 23(1), 191-208

Bardhan, P. (1989). The new institutional economics and development theory: A brief critical assessment. World Development, 17(9), 1389-1395

Commons, J. R. (2001). "Institutional economics" the American economic review 1931, vol. XXI, n 4, pp. 648-657. Cahiers d'économie Politique/Papers in Political Economy, (40/41), 287-296.

Furubotn, E. G., \& Richter, R. (2010). Institutions and economic theory: The contribution of the new institutional economics. Ann Arbor: University of 
Michigan Press

Goldfield, M., \& Gilbert, A. (2018). - The Limits of Rational Choice Theory. In Race and Representation. Routledge

Hausman, D. M., \& Mcpherson, M. S. (1993). Taking Ethics Seriously: Economics and Contemporary Moral Philosophy. Journal of Economic Literature, 31(2), 671-731

Hayami, Y., \& Kikuchi, M. (1999). A rice village saga: Three decades of green revolution in the Philippines. Rowman \& Littlefield Publishers.

Huberman, M. B. M. dan A. M. (2014). Analisis Data Kualitatif, Buku Sumber Tentang Metode-Metode Baru. Jakarta: Penerbit Universitas Indonesia (UI-Press).

Kasper, W., \& Streit, M. E. (1999). Institutional economics. Edward Elgar Publishing

Krishna, A., \& Uphoff, N. (1999). Mapping and measuring social capital: A conceptual and empirical study of collective action for conserving and developing watersheds in Rajasthan, India. The World Bank.

Libecap, G. D. (1989). The Political Economy of Crude Oil Cartelization in the United States, 1933-1972. The Journal of Economic History, 49(4), 833-855

Lincoln, A. (2010). Ekonomi Pembangunan, Edisi Ketiga. Yogyakarta: STIE YKPN.

Miller, R. le R. et al. (1977). Teori Ekonomi Mikro Intermediate. Jakarta: Raja Grafindo Persada.

North, D. C. (1994). Economic performance through time. The American Economic Review, 84(3), 359-368.

Ostrom, E. (1990). Governing the Commons: The Evolution of Institutions for Collective Action (Political Economy of Institutions and Decisions). Cambridge University Press

Ritzer, G., \& Goodman, D. (2001). Postmodern social theory. In Handbook of sociological theory (pp. 151-169). Springer.

Rohima, S. R. (2013). Vicious Circle Analysis of Poverty and Entrepreneurship. IOSR Journal of Business and Management, 17(1), 33-46.

Sudaryanto, A. (1999). Sistem Perkawinan Pada Masyarakat Kalang Studi Kasus di Kampung Ngoto dan Tegalgendu Yogyakarta. Mimbar Hukum, 10 (33)

Suradisastra, K. (2008). Perspektif Sosial-Budaya Dalam Pengembangan Pertanian Timur Indonesia. Menyoroti Dinamika Pembangunan Pertanian Kawasan Timur Indonesia: Prosiding Lokakarya, 9.

Williamson, O. E. (2000). The new institutional economics: Taking stock, looking ahead. Journal of Economic Literature, 38(3), 595-613.

Yeager, T. J. (1999). The development of the metacognitive elements of study scale. [Dissertation]. University of North Dakota

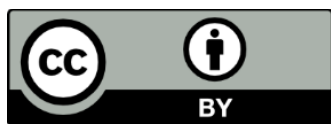

(C) 2021 by the authors. Licensee JPPD, Indonesia. This article is an open-access article distributed under the terms and conditions of the Creative Commons Attribution (CC BY) license (http://creativecommons.org/licenses/by/4.0/). 